\section{Her Voice: Engaging and Preparing Girls With Disabilities for Science, Technology, Engineering, and Math Careers}

\author{
Amy Jane Griffiths ${ }^{a}$, Angel Miles Nash ${ }^{b}$, Zachary Maupinc, \\ Sneha Kohli Mathurd
}

$\begin{array}{ll}\text { Received: } & 7 \text { October } 2019 \\ \text { Revised: } \quad 2 \text { December } 2019 \\ \text { Accepted: } \quad 29 \text { December } 2019 \\ \text { ISSN: 1307-9298 } \\ \text { Copyright ( } \text { IEJEE } \\ \text { www.iejee.com }\end{array}$

DOI: 10.26822/iejee.2020358223

\begin{abstract}
Science, technology, engineering, and math (STEM) related fields comprise the top 30 occupations expected to grow the fastest by 2026 . This increase in job opportunities, coupled with the evolution of technology, is creating higher demands for diversity in the labor market. Currently all students require innovative training and support from a young age to pursue STEM careers successfully. However, women and girls with disabilities face unique barriers along the STEM education pipeline. In this paper, we report the current and projected labor market trends in the United States. We then consider how this labor market information can be used by elementary educators to engage girls with disabilities in STEM-related learning effectively. Finally, through our analysis of labor market needs and the available assessment and intervention literature, we present a science-informed framework for intervention.
\end{abstract}

Keywords: STEM Education, Girls with Disabilities, Transition, Career Planning

\section{Introduction}

In the United States, more than 156 million jobs are available, with projections of $0.7 \%$ annual increases in available jobs over the next 10 years (U.S. Department of Labor, Bureau of Labor Statistics, 2017a). We must consider the influence of science, technology, engineering, and math (STEM)-related professions as employment opportunities and options increase. To this point, $15 \%$ of the U.S. workforce is in computer, engineering, and science careers; these and other STEM-related fields comprise the top 30 occupations expected to grow the fastest by 2026 (U.S. Department of Labor, Bureau of Labor Statistics, 2017b, 2018a). This progressive increase in job opportunities, coupled with the evolution of technology, is creating higher demands for diversity of thought, experience, perspective, and background in the labor market.

Currently all students require innovative training and support from a young age to pursue STEM careers successfully; however, girls and women with disabilities face additional unique barriers (National Science Foundation, 2015). These obstacles are embedded in interpersonal, social, communal, and sociocultural systems that require intentional changes to policy and procedures (Harley, 2011; O'Day \& Foley, 2008). For girls and women with disabilities, these opportunities must take into account the systems that surround their path through education and early career development. Despite a lack of research on girls and women with disabilities in STEM-related fields, there is an undeniable need for improving this trajectory for current students and those to come.

Our approach in this paper considers the needs of the labor market, as well as students' distinct ecological factors, which can influence and inform effective intervention. By analyzing state and national labor market data, we intend to support educators in early and comprehensive preparation for successful post-K-12 education and workforce transitions for girls and women with disabilities in STEM-related fields.
Science, Technology, Engineering, and Math Workforce: The Future's Demand and Diversity

The rapidly increasing pace of technology advancement has and will continue to influence social and educational change. School settings sustain undeniable impacts as educators continually prepare their students for technology-driven futures. Future labor markets demand earlier preparation to best support student workforce transitions. Likewise, education's response to the diverse positionalities of students offers essential opportunities for schools to intentionally plan and implement meaningful programming. The historicity of exclusion in the STEM pipeline establishes a foundational need to support students who have been historically marginalized. These marginalized groups include individuals with disabilities (Griffiths, Giannantonio, Hurley-Hanson, \& Cardinal, 2016) and girls and women (Noonan, 2017). When demands for STEM-related skills meet students' needs for transition support, we set pedagogical precedence for providing more innovative supports.

In response to modern sociotechnological advances, educators are compelled to pursue and provide more innovative means of preparing students to learn and integrate technical knowledge and skills effectively. Furthermore, policy directives charge public schools with providing transition services for students as they ready to leave the educational system and enter the workforce (Lee, 2011). For example, the Individuals With Disabilities Education Act (IDEA, 2004) mandated that schools develop individualized transition plans before 16 years of age for students who receive special education services. The federal government has outlined that individualized transition plans are to consist of assessment information, present levels of performance, transition services necessary to support progress, a yearly review of postsecondary goals, and a summary of progress. A student's regular individualized education program team members are responsible for devising and implementing this plan based on the student's interests, strengths, and ability level. Integrating these components into a successful strategy for 
transitioning is intended to promote independent living, additional education, and career readiness.

A looming reality of an increasingly competitive and automated workforce is approaching both students and educators (Institute for the Future \& Dell Technologies, 2017; World Economic Forum, 2018). Additional factors such as artificial intelligence and the growing STEM-education requirements for participating in the workforce may present themselves as barriers to individuals with disabilities who are unprepared or untrained. These challenges may become amplified by disproportionality of opportunity and a lack of effort on behalf of companies to make the workforce more inclusive. Understanding the nuances and effects of these obstacles requires a separate investigation of individuals with disabilities and women in the STEM workforce.

Students With Disabilities Pursuing Science, Technology, Engineering, and Math

Researchers have explored how similar suggestions can be useful for students and employees who live similar intersectional realities (Griffiths \& Miles Nash, 2019). The similarities across these investigations include the need for transition planning from high school into the workforce or higher education. While there has been a progression in this area, there is room for improvement that specifically addresses individuals' unique perspectives. For example, there is some research highlighting the positionalities of girls and women in STEM (Modi, Schoenberg, \& Salmond, 2012).

Throughout history, individuals with disabilities have been marginalized in their access to employment opportunities (Griffiths et al., 2016). Employment outcomes for these individuals are drastically lower than those without disabilities, with as little as $21 \%$ of individuals with disabilities reporting gainful employment (U.S. Department of Labor, Bureau of Labor Statistics, 2018b). With as few as 7\% of the science and engineering workforce reporting a disability, the National Science Foundation (2015) stated substantial barriers are present for individuals with disabilities, in addition to women and minority ethnic and racial groups, accessing STEM-related jobs. Unfortunately, this issue persists with a sparse number of recruitment programs identified in research and a general lack of discussion in special education (Fichten et al., 2003; Marino, 2010). Despite encountering these obstacles, students with disabilities have shown great success in pursuing postsecondary education and careers in STEM-related fields (Bellman, Burgstahler, \& Chudler, 2018; Schreffler, Vasquez, Chini, \& James, 2019).

Lee (2011) found an increase in college enrollment for students with disabilities, with approximately $22 \%$ pursuing a STEM major. Further findings implied positive experiences for students with disabilities, often enrolling in community colleges before transitioning to well-compensated STEM careers or continued postsecondary education (e.g., 4-year colleges). Unfortunately, students with select disabilities present a much higher risk of struggling to complete or finish college degrees in STEM (Stamp, Banerjee, \& Brown, 2014). A large body of research has indicated teachers struggle to facilitate inclusive STEM classrooms and may require additional training and skills to increase access and learning for students with disabilities (Bargerhuff, Cowan, \& Kirch, 2010; Lee, 2011; Rule, Stefanich, Haselhuhn, \& Peiffer, 2009). This population of students is underrepresented in traditional designs for instruction.

We have made improvements in the process of transition planning for students with disabilities who are transitioning from high school to the workforce or further education. However, increased conversations on topics of universal design for learning (UDL) and instruction are pivotal in supporting students with disabilities to pursue STEM education and careers (Izzo \& Bauer, 2015; Schreffler et al., 2019). Originally, UDL was developed in the field of architecture to encourage product designs to support an environment more accessible to all people. Universal design has grown to be present in a variety of disciplines in education, including instruction and learning (Schreffler et al., 2019). Universal design promotes consideration being given to an individual's ability or skill level, learning preference, age, gender, sexual orientation, culture, and disabilities (Burgstahler, 2017).

Three critical factors in UDL include providing multiple means of engagement, representation, and action and expression (Center for Applied Special Technology [CAST], 2011a). These principals represent the why, what, and how of learning, respectively. They are intended to support learners who are purposeful and motivated, resourceful, and knowledgeable, as well as strategic and goal-directed (CAST, 2011b). The CAST developed general guidelines for integrating UDL into teaching and learning. These aspects of learning are essential assets for increasing access to STEM curriculum for students with disabilities (Schreffler et al., 2019).

Women With Disabilities in Science, Technology, Engineering, and Math

Girls and women with disabilities face a unique crossroads during their educational experiences and when preparing for workforce transitions as a result of their multiple marginalized identities. As the representation and understanding of girls with disabilities in the STEM pipeline are marked by severe disproportionality in research and literature, we have chosen to focus on women as an indicator of how gender may inform girls' experiences. Being a woman with a disability has been likened to double jeopardy due to the related disadvantages that can impact transition outcomes in pursuing further education or careers (Harley, 2011). The elements of an individual's gender orientation and disability classification are inseparable and uniquely combine to result in their identity as a person. Unfortunately, there is a substantial lack of scholarship on girlhood or womanhood in conjunction with a focus on disability classification. This underrepresentation further demands attention and action to promote equity and inclusion of both gender and ability in STEM education research.

Historically, women have encountered inequities in the workplace and education (Noonan, 2017; Sumi, 2012). The resulting disproportion is further represented in STEM, as men in 2015 occupied $76 \%$ of STEM jobs, while total job distribution was reported to be $53 \%$ men and $47 \%$ women (Noonan, 2017). The Society of Women Engineers (2018) reported, despite substantially reducing the discrepancy between boys and girls completing STEM courses in high school over the past 30 years, only $9.5 \%$ of female freshmen pursued STEM majors compared to $27.9 \%$ of males. Additionally, over $32 \%$ of women changed majors from STEM programs, and only $30 \%$ who earned bachelor's degrees in engineering continued to work in engineering 20 years after earning their degrees.

Recent reports indicate women in STEM represent $13 \%$ of engineers, $26 \%$ of computer scientists, $17 \%$ of tenured/tenure-track engineering faculty, and $28.4 \%$ of positions in science and engineering occupations (National Science Foundation, 2017a; Society of Women Engineers, 2018). However, a continued wage gap exists between men and women in select STEM fields (Society of Women Engineers, 2018). Moreover, while women's participation in the U.S. labor force has shown substantial advancement over time, this progress has declined in the 21st century-most notably in women with less educational experience (Black, Whitmore, Schanzenback, \& Breitwieser, 2017). The absence of women in the workforce and education has a substantial impact on equitable opportunities and economic growth overall (Bandara, 2015).

Gender disproportionality presents a more-than-obvious gap in the field of STEM; this gap grows even wider when we con- 
sider disability classifications. Women with disabilities are subject to daunting vulnerabilities in the labor market, including unemployment, underemployment, negative work experiences, increased workplace demands, and more overall insecurities related to work (Harley, 2011). Griffiths and Miles Nash (2019) reviewed further sociocultural factors that contribute to this discrimination, including stereotype threat, implicit bias, and a lack of targeted professional supports that stunt women's success and thriving in STEM fields. These hurdles are evident in findings where women with disabilities are employed at substantially lower rates $(34.5 \%)$ than men with or without disabilities $(41.9 \%$ and 85.6\%, respectively; O'Day \& Foley, 2008).

Given these barriers to successful employment, we must be focused and strategic when career planning for girls with disabilities. As $85 \%$ of the employment opportunities available in 2030 are for jobs that do not yet exist (Institute for the Future \& Dell Technologies, 2017), it is essential to develop systemic pathways that include the contributions of employees who offer unique and varied manners of approaching and completing tasks. In particular, women with disabilities are equipped to offer a range of contributions based on their abilities to navigate educational and professional spaces not originally designed to include them. Using available labor market data can be particularly helpful in securing long-term employment. It can help students and education professionals create pathways to careers in which students can support themselves (Justice \& Norwood, 2016). Supporting Transition Stakeholders and Structures With an Eco-
logical Systems Approach

Ecological systems theory is an approach that considers individuals interacting in and throughout various layers of their immediate settings, including their physical, social, and cultural environments over time (Bronfenbrenner, 1977). An individual's development is impacted by the settings in which they directly interact and by the larger systems indirectly connected to them; Bronfenbrenner (1979) believed human development is best understood by considering all systems in which the individual is embedded and their dynamics. These interaction effects are multidimensional, with each person and system influencing and being influenced by one another. Bronfenbrenner's $(1977,1979)$ work on ecological systems theory is accepted widely and used extensively across a variety of research topics (Neal \& Neal, 2013).

In our consideration of the contextual factors impacting the career preparation of girls with disabilities, an ecological framework lends itself well to identifying details and specific supports to promote early preparation for STEM-transitions. As early as 1991, Hanna and Rogovsky examined systems influencing women with disabilities in the workforce. They proposed a simplified, triangular model observing factors including sociocultural, self-concept, and participation for women with disabilities. These three foundational components were described as being interactive parts of a much more complex set of dynamics involving one's participation across individual resources, physical condition, participatory behavior, as well as attitudes toward self and others and community level resources, physical environment, cultures, subcultures, and patterns of behavior (Hanna \& Rogovsky, 1991).

Similarly, when bringing an ecological perspective to social inclusion practices, the domains of interpersonal relationships and community participation have continued to be used as structural components (Simplican, Leader, Kosciulek, \& Leahy, 2015). Ecological layers, including individual, interpersonal, organizational, community, and sociopolitical levels, were used to consider their influence on interpersonal relationships and community participation. This emphasis on social interaction and relationships throughout each sys- tem level is the foundation for a networked model of ecological systems (Neal \& Neal, 2013). Using labor market data to inform our approach, we have built on these models to support an ecological systems framework that focuses on the individual's participation and relationships across their home, community, and culture as they progress from preschool through 12th grade, higher education, and into employment (Griffiths \& Miles Nash, 2019).

Our framework was developed to emphasize the individual's participation and relationships throughout relevant systems involved in pursuing postschool and workforce transitions. Girls with disabilities cannot effectively participate in these relationships and systems if school teams are not aware of the needs in those systems. To encourage participation and success, we must understand the needs of the labor market and integrate this information into our intervention framework. Specifically, in the employment system, we must know the types of skills needed and positions available as we prepare girls with disabilities for future careers. Then, we must integrate this labor market information into our approach across all levels.

It is essential to facilitate collaboration among team members in girls' homes, schools, and future employment settings to prepare for the change across levels and systems. Team members are encouraged to expand their awareness and knowledge to be more mindful and intentional in their planning, connecting student interests and goals with appropriate curriculum and resources to increase diversity. This exposure will continue to bridge the gaps women with disabilities face when pursuing STEM-related fields, thus supporting their needs and goals. These steps are intended to help identify and match individual student needs to interventions and support across each system. This approach builds on the FACES model we discuss in the Intervention section of this paper (Griffiths \& Miles Nash, 2019). This paper is focused explicitly on interest and employment in STEM fields, and it may not apply to some individuals who require significant support or who do not have an interest in these areas. However, the framework was developed specifically using labor market information to assess and plan for interventions that may apply to everyone.

We established an overarching goal to support early transition planning for girls with disabilities interested in STEM considering curriculum, pedagogy, and interventions across levels. When addressing the critical points of intervention for preparing girls in STEM, we propose intervening at the following systems levels: (a) individual, (b) preschool through 12th grade (PK-12), (c) higher education, and (d) employment, each uniquely influenced by home, community, cultural systems (see Figure 1).

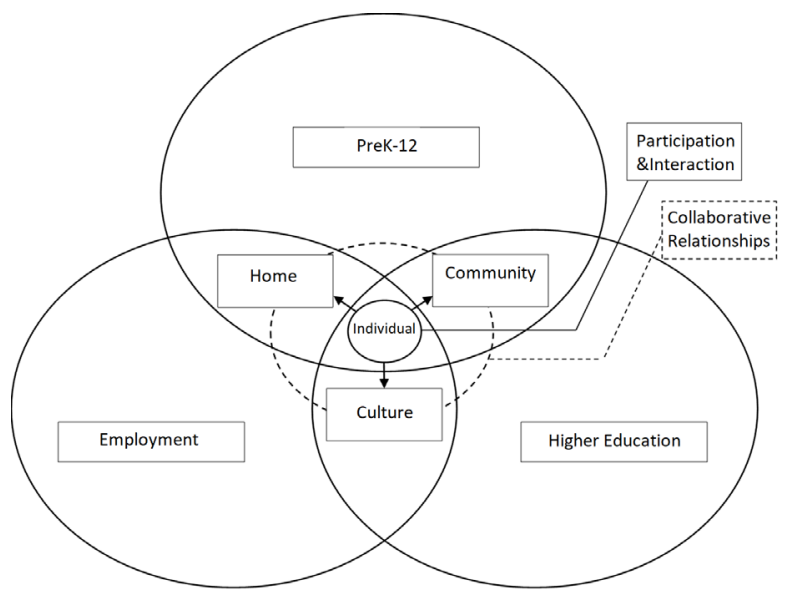

Figure 1. A systems theory framework for transition planning. 
Given this topic is in its infancy in terms of research and practice, in this paper, we begin to explore ways in which we can apply what we do know to the challenges identified in the literature. We consider the following questions:

- What are current labor market trends and 10-year projections, particularly in STEM fields, for the United States, and a sample state (i.e., California)?

- How can teams use this labor market information in an ecological systems approach to engage girls with disabilities in the identified STEM fields?

Understanding Current Labor Market Data to Inform Assessment and Intervention

Not enough is being done to adequately prepare individuals with disabilities, particularly girls, to be competitive in the changing labor market. Accurate real-time data must be used to help inform the process of preparing students for meaningful careers in the future labor market. Government-collected data sources have not kept pace with the rate of change in rapidly transforming occupations such as cybersecurity, Internet of things, and blockchain. Using real-time data, we can obtain the most current job skills, occupations, and certifications these industries require. These data were not available a few years ago. Now, high schools, school counselors, colleges, and future employers will not be able to prepare girls with disabilities for employment without understanding the landscape of the future of work. Often, there is an increased focus on getting the individual with a disability any job, but there is little focus on the needs of the global economy. It is critical to understand how best to support these individuals in building a life that includes a sustainable and meaningful career with a livable wage.

\section{Data Collection: Current Labor Market Trends}

Labor market data provided by Walrod and Walrod (2018) consisted of labor market information, economic data, and real-time job posting data. The data collection effort harmonized dozens of public and state labor market sources, including the Bureau of Labor Statistics, the U.S. Census Bureau, and the Bureau of Economic Analysis. A variety of proprietary data sources and analytic tools were also used in data collection and analysis, specifically data from real-time labor market information providers such as Emsi and Burning Glass. We can assess the labor market needs by looking at necessary and high-demand job skills, available jobs, and projected job growth in the next 10 years (Griffiths, Cosier, \& Morgan, 2019).

\section{Job Skills}

Rather than looking solely at specific jobs, it helps to isolate the skills most often required in the labor market; this allows us to prepare individuals with the specific skills needed rather than for a potential position, which may evolve or disappear in the future.

\section{Necessary Skills}

The top necessary skills for current job postings are detailed in the following sections. Necessary skills fall into two categories: baseline skills and specialized skills. Baseline skills are foundational skills that are intangible and may be transferable to other positions or careers, such as creativity or innovation. Specialized skills include completing tasks that are more technical or hybridized and require training, such as coding or budgeting. Specific in-demand skills were prioritized based on the number of job postings that included these skills in the posting.

Based on the number of job postings from the labor market sources mentioned previously, the following are considered the top four in-demand baseline skills in the United States: (a) communication skills (7 542240 job postings), (b) teamwork/ collaboration (3 765154 job postings), (c) organizational skills (3 356446 job postings), and (d) problem solving (2 961468 job postings). The top four specialized skills with the highest number of job postings in the United States included: (a) customer service (4 017926 job postings), (b) sales (2 853731 job postings), (c) scheduling (2 797461 job postings), and (d) budgeting (1 850345 job postings). Depending on the stakeholder's location, it might be helpful to look at both national and local information (Griffiths et al., 2019).

When planning for employment programs in specific regions, it is helpful to compare national data to in-state data trends. For example, in California, the following are considered the top four in-demand baseline skills based on the number of job postings in which they appeared: (a) communication skills (1 115417 job postings), (b) teamwork/collaboration (588 379 job postings), (c) organizational skills (514 286 job postings), and (d) skills in Microsoft Excel (458 871 job postings). The top four specialized skills in California and the associated number of job postings included: (a) customer service (520 617 job postings), (b) scheduling (394 635 job postings), (c) sales (378 904 job postings), and (d) budgeting (272 047 job postings). Educators may also be interested in comparing national and state data to county-specific information, which are also available using the same databases. Key stakeholders may use these data to build employment intervention programs focused on the skills needed in their geographic location.

Many STEM-related jobs include the need for software and programming skills. The job posting data indicate the following skills are in high demand in the United States: Microsoft Excel, Microsoft Office, Microsoft Word, Microsoft PowerPoint, Structured Query Language (SQL), Java, software development, Oracle, JavaScript, Python, SAP, Linux, and software engineering.

\section{High Demand Skills and Top Qualifications}

In addition to understanding the necessary skills, it is helpful to know the level of supply and demand for relevant skills as well as the specific qualifications that may be in high demand. We calculated supply and demand by comparing the frequency of specific skills present in job postings against skills present in the current workforce. Along with job posting analytics, this comparison used a dataset of more than 100 million online resumés and profiles. All resumés and profiles used in these comparisons have been updated in the last three years. The skills associated with workforce profiles represent employees at all levels of education, training, and experience. The job skills were then categorized into hard skills, common skills, and top qualifications. We present the most relevant hard and common skills in STEM-related fields in the following sections. To identify a discrepancy in supply and demand, we compared two percentages. The first percentage was calculated by dividing the job postings with the identified skill by the total number of job postings during a two-year period. The second was calculated by dividing the job-seeker profiles with the specified skill by the total number of profiles during the same two-year period. We calculated the discrepancy in supply and demand by subtracting the frequency in postings from the frequency in profiles. For these skills, the more employers seek the listed skill, and the fewer people there are listing these skills in their online profiles, the higher the number will be (Griffiths et al., 2019).

Hard skills in STEM fields mostly included taking care of others, particularly in the medical field. These jobs included nursing (4.08\% discrepancy), intensive care work $(1.48 \%$ discrepancy), basic life support (1.41\% discrepancy), surgeries (1.27\% discrepancy), acute care (1.24\% discrepancy), advanced cardiovascular life support (1.15\% discrepancy), pediatrics (.92\% discrepancy), and rehabilitation work (.78\% discrepancy). Common skills cut across multiple fields and may be particularly important when teaching individuals with 
disabilities-the skills needed to be successful in the STEM workforce. The STEM-related skills in high demand included: communications (10.29\% discrepancy), innovation (5.89\% discrepancy), written communication (3.69\% discrepancy), interpersonal skills $(2.93 \%)$, management $(2.49 \%)$, verbal communication skills ( $2.41 \%$ discrepancy), problem solving (2.38\% discrepancy), computer literacy (2.36\% discrepancy), decision making (1.38\% discrepancy), mentorship (.86\% discrepancy), operations (.76\% discrepancy), and coordinating (.10\% discrepancy).

\section{Available and In-Demand Jobs}

Along with these skills, many in-demand jobs include specific qualifications. Of those top qualifications needed in current job postings, many are related to STEM fields. These included: licensed practical nurse (884 993 job postings), critical care registered nurse (645 344 job postings), CNOR certification, a certification program for perioperative nurses (604 082 job postings), nurse practitioners (567 372 job postings), certified nursing assistant (494 871 job postings), licensed vocational nurses (308 513 job postings), certified information systems security professionals (171 483 job postings), patient care technicians (151 763 job postings), American registry of radiologic technologists (128 977 job postings), and certified information security manager (128 939 job postings).

After a skills analysis is complete, stakeholders should begin to evaluate the types of jobs currently open and available for students who are in need of employment. Included in this section is a list of jobs actively available in the United States with the average active number of job postings for the last two years. The analysis was limited to active postings of the top 1.000 jobs. Job postings were listed for the United States and for a sample state to demonstrate the types of data available (Griffiths et al., 2019). In the United States, STEM-related jobs included registered nurses (238 595 job postings), software engineers (81 648 job postings), physicians (75 638 job postings), and maintenance mechanics (52 008 job postings). In our sample state, California, we found similar results. Specifically, there are several job postings for registered nurses (20 659 job postings), software engineers (20 248 job postings), physicians (5.275 job postings), speech and language pathologists (4.937 job postings), and design engineers ( 4.881 job postings).

\section{Projected Job Growth}

Projected job growth allows educators to support girls with disabilities in preparing for jobs likely to be soon in demand in the United States. To calculate the skills projection information, Walrod and Walrod (2018) used econometric time series models with machine learning methodology to predict growth in job posting demand for skills. Projected job growth was calculated using the percentage change in the largest occupations over the next 10 years (2018-2028). We have included data for the United States and for California to illustrate similarities and differences by region (Griffiths et al., 2019).

In the United States and California, personal care aide positions were projected to grow the most, with a $37.60 \%$ change in the United States and a $41.8 \%$ change in California. When focusing on STEM-related fields, registered nurses $(15.4 \%$ change), postsecondary teachers (13.30\% change), and maintenance and repair workers $(10.03 \%$ change) will be in high demand. In California, software developers $(31.4 \%$ change), registered nurses (17.3\% change), and postsecondary teachers (12.1\% change) will be in high demand.

Now that we have developed a sense of the labor market needs currently and in the next 10 years, we must consider how teams can use this labor market information. We are particularly interested in applying it in an ecological systems approach to engage girls with disabilities in the identified STEM fields.

\section{Application: Creating an Assessment and Intervention Framework Based on the Data}

Labor market information should be applied throughout the assessment and intervention process. In the following sections, we provide concrete suggestions for using this information, while considering the ecological systems in which girls with disabilities are embedded.

\section{Assessment}

Once we have gathered some necessary labor market information, we can begin the planning and intervention process. Rowe, Mazzotti, Hirano, and Alverson (2015) highlighted the Blueprint for Reform, which outlined a guide to incorporate assessments for students to support their successful transition to college and career endeavors. The five steps for service providers to collaborate on include: (a) determining what to assess, (b) selecting the appropriate assessments, (c) conducting the assessments, (d) analyzing the assessment results, and (e) signing the assessment data for planning and intervention. The traditional transition planning process is typically conducted annually with little input from the student and is focused on the student's current capabilities, weaknesses, and identified disabilities. Rowe et al. (2015) proposed having the assessment process be ongoing, with the student playing an active role and focusing on their strengths and how they can use those strengths for future roles in employment and the community. We suggest that professionals incorporate current and future labor market needs into this planning process.

When creating a plan for transition, many professionals may use occupational and skills assessments such as the O*net (2019), Casey Life Skills (2017), PAIRIN (2017), MindTools (2019), MBTI (Myers Briggs Foundation, 2019), Career Beliefs Inventory (Mind Garden, 2019), Career Keys (Jones, 2014), and Reflect (Graduate Management Admission Council, 2014). There are also online resources, such as careeronestop.org, that have a combination of assessments and toolkits to help match assessment outcomes with potential jobs. Individuals may consider how their assessment data reflect the needs of the labor market and take additional care to think about the unique needs of girls with disabilities in the current ecological setting. Some questions to ask during this assessment process include:

1. Given labor market data, are we assessing in the right areas (i.e., hard skills/soft skills needed in the STEM fields)?

2. Do the outcomes of our assessment match up with the current and future projected needs?

3. If there is a discrepancy between assessment data and labor market needs, what data do we need?

\section{Intervention}

As we considered the various systems that impact individuals' development and the available research in related areas, we identified five critical points of intervention. The labor market must inform the points of intervention to provide the appropriate preparation and skills training in this framework. These interventions are used to enhance STEM employment and engagement outcomes for historically underserved individuals. The FACES framework represents the many faces of diversity. By using this framework to shape our approaches across systems, we endeavor to improve access to meaningful and long-lasting employment. We define the five components of the FACES intervention framework in the following sections. 


\section{Facilitation}

Effective collaboration is associated with positive outcomes for students and is a critical component of providing equitable educational opportunities. To have a collaborative team approach across systems, school professionals must facilitate open communication and develop shared goals for the future (Griffiths, Alsip, Hart, Round, \& Brady, in press). When considering career-focused planning for individuals with disabilities, we should start as early as elementary school to develop work-related behaviors (e.g., social skills, work ethic, problem-solving skills, dependability, following through on tasks, following directions; Blalock \& Patton, 1996). Also, training teams on future-focused planning using labor market data and intervention will allow everyone to share a similar vision for the child. Collectively, school professionals can facilitate change with the common understanding that the world is evolving, and we need to prepare our youth for these changes.

\section{Awareness}

Awareness refers to broadening individuals, institutions, and communities' knowledge of the need for girls and women with disabilities to be included in STEM fields. Girls and women with disabilities have a unique and necessary perspective to offer in various STEM fields. We must increase and sustain an understanding of their positive influence on the world through STEM (Joseph, Hailu, \& Boston, 2017; Tabak \& Collins, 2017).

Table 1. FACES: Levels of Intervention for Facilitating Transitions

\begin{tabular}{|c|c|c|c|c|c|}
\hline System & $\begin{array}{l}\mathrm{F} \\
\text { Facilitation }\end{array}$ & $\begin{array}{l}\text { A } \\
\text { Awareness }\end{array}$ & $\begin{array}{l}\text { C } \\
\text { Connection }\end{array}$ & $\begin{array}{l}\text { E } \\
\text { Exposure }\end{array}$ & $\begin{array}{l}\text { S } \\
\text { Support }\end{array}$ \\
\hline Individual & $\begin{array}{l}\text { Individuals help pick } \\
\text { their team } \\
\text { Teach self-advocacy } \\
\text { and goal setting }\end{array}$ & $\begin{array}{l}\text { Understand and assess } \\
\text { strengths and struggles } \\
\text { related to skills needed } \\
\text { Self-advocacy in sharing } \\
\text { value }\end{array}$ & $\begin{array}{l}\text { Match interests and } \\
\text { skills to the labor market } \\
\text { needs } \\
\text { Career assessment }\end{array}$ & $\begin{array}{l}\text { Unique skills and } \\
\text { needs matched } \\
\text { to mentors and } \\
\text { models }\end{array}$ & $\begin{array}{l}\text { Person-centered } \\
\text { assessment and labor } \\
\text { market informed } \\
\text { planning } \\
\text { Targeted intervention } \\
\text { based on strengths } \\
\text { and struggles }\end{array}$ \\
\hline PK-12 & $\begin{array}{l}\text { Training teachers, } \\
\text { staff, counse-lors, and } \\
\text { parents } \\
\text { Develop a shared } \\
\text { vision and goals }\end{array}$ & $\begin{array}{l}\text { Professions and careers } \\
\text { impact on society } \\
\text { Start early }\end{array}$ & $\begin{array}{l}\text { "Hands-on" curriculum } \\
\text { and learning } \\
\text { Future aspirations devel- } \\
\text { op-ment } \\
\text { Internship and work } \\
\text { experi-ence }\end{array}$ & $\begin{array}{l}\text { Mentors } \\
\text { Access to special } \\
\text { programs }\end{array}$ & $\begin{array}{l}\text { School counselors and } \\
\text { service providers } \\
\text { Accommodations such } \\
\text { as sign language needs } \\
\text { and technology } \\
\text { Adapted curriculum }\end{array}$ \\
\hline Higher Ed & $\begin{array}{l}\text { Communicate with } \\
\text { PK-12 schools to } \\
\text { share requirements } \\
\text { and needs to facilitate } \\
\text { students enter-ing } \\
\text { with the necessary } \\
\text { skillset }\end{array}$ & $\begin{array}{l}\text { Targeted campaign } \\
\text { Sponsor events } \\
\text { Organizational partner- } \\
\text { ships }\end{array}$ & $\begin{array}{l}\text { Career planning } \\
\text { Add voice and agency }\end{array}$ & $\begin{array}{l}\text { Professors } \\
\text { Mentors and role } \\
\text { models } \\
\text { Tailored classes }\end{array}$ & $\begin{array}{l}\text { Instructor support } \\
\text { Childcare } \\
\text { Accommodations in } \\
\text { institutions } \\
\text { Universal Design for } \\
\text { Learning }\end{array}$ \\
\hline Employers & $\begin{array}{l}\text { Work with outside } \\
\text { agencies and schools } \\
\text { to create a pipeline }\end{array}$ & $\begin{array}{l}\text { Demonstrate how } \\
\text { diversity adds value to } \\
\text { organizations } \\
\text { Change in gendered } \\
\text { mispercep-tions }\end{array}$ & $\begin{array}{l}\text { Career training } \\
\text { Diversity adds value } \\
\text { Employer initiatives }\end{array}$ & $\begin{array}{l}\text { Leadership exam- } \\
\text { ples } \\
\text { Understand the im- } \\
\text { pact of individuals } \\
\text { with disabilities in } \\
\text { positive and lasting } \\
\text { ways }\end{array}$ & $\begin{array}{l}\text { Hiring application and } \\
\text { inter-view adjustments } \\
\text { Accommodations for } \\
\text { diversity of support } \\
\text { across disciplines } \\
\text { Training for employ- } \\
\text { ees with and without } \\
\text { disabilities }\end{array}$ \\
\hline $\begin{array}{l}\text { Home/ } \\
\text { Communi-ty/ } \\
\text { Cultural }\end{array}$ & $\begin{array}{l}\text { Build relationships } \\
\text { with schools and } \\
\text { employers to set up } \\
\text { learning opportunities } \\
\text { for students and staff }\end{array}$ & $\begin{array}{l}\text { Community events } \\
\text { Mindful of messages } \\
\text { conveyed and language } \\
\text { used regarding girls } \\
\text { with disabilities involve- } \\
\text { ment in STEM careers }\end{array}$ & $\begin{array}{l}\text { Connect STEM work to } \\
\text { changing the world } \\
\text { Discuss as an attainable } \\
\text { possibility } \\
\text { Apply to the activities to } \\
\text { the individual's cultur-al/ } \\
\text { community context }\end{array}$ & $\begin{array}{l}\text { Parents and schools } \\
\text { create opportuni- } \\
\text { ties for community } \\
\text { exposure } \\
\text { Include everyone in } \\
\text { special events } \\
\text { Enroll in camps and } \\
\text { en-richment }\end{array}$ & $\begin{array}{l}\text { Outside and in-home } \\
\text { supports (e.g., tutors) } \\
\text { with awareness of bias } \\
\text { Accommodations } \\
\text { in multiple contexts } \\
\text { based on specific } \\
\text { needs }\end{array}$ \\
\hline
\end{tabular}

Note: Adapted from Making STEM Education Inclusive: Opening Doors to Engage Girls and Women With Disabilities, by A. J. Griffiths \& A. M. Nash, 2019.
Connection

Connection means creating opportunities for girls to understand the relationship between their current STEM learning and their professional and personal aspirations in the future. When girls see how their use of STEM positively impacts the pipeline from education to employment (Modi, Schoenberg, \& Salmond, 2012). Our approaches must encourage them to contribute their voice and value through their involvement in STEM. This connection is attainable through engaging handson curricula relatable to their surrounding context (Bystyployment needs in their communities.

\section{Exposure}

Providing access to the types of jobs and activities in which they can participate is critical to meaningful exposure. Opportunities for training, internships, and mentorship should be made available to girls across developmental levels and settings (e.g., in special education programs, in the community). Likewise, along their educational paths, access to educators and STEM-related professionals with whom they have an affinity helps girls with disabilities persist, as it demonstrates success and fulfillment in STEM careers are a real possibility (Feldhaus \& Bentrem, 2015; Fifolt \& Searby, 2010; Kendricks, Nedunuri, \& Arment, 2013). School teams can use labor market data to identify potential employers in need of skilled emworld around them, they are more likely to persist in the STEM dzienski, Eisenhart, \& Bruning, 2015) and informed by the em- 
ployees and develop partnerships to increase exposure and training in STEM careers for girls with disabilities.

Support

Support refers to offering evidence-based tools, accommodations, and approaches for success at each educational and professional level. It is critical that support is based on the needs of the individual, in the context of the subject matter, and occurs early and often in STEM education and professional settings (Izzo \& Bauer, 2015; Lee, 2011). Educators must encourage the inclusion of girls with disabilities in STEM opportunities in school setting. They must advocate these opportunities as directly linked to the needs of the STEM employment community through the use of data.

When developing a systemwide plan to address the needs of girls with disabilities across the various FACES domains, educators may ask the following questions: (a) Does our plan lead to sustainable outcomes for girls with disabilities? (b) Does it include real-life opportunities for them to practice and receive feedback on skills from individuals who represent them? (c) Do our services match student strengths, goals, and needs? and (d) Are we collecting data on progress toward long-term employment? We must also consider how to use labor market data throughout the process. We can then use this data to facilitate discussion across stakeholders, encouraging open discussions across all members of the system along the pipeline. We can use this information to assess relevant areas and create transition plans that include the right supports, particularly those that support the acquisition of the necessary skills. We can also consider training educators and supporters across contexts to focus their efforts on the projected needs of the national and local context.

\section{Conclusion}

Through our analysis of labor market needs and the current assessment and intervention literature, we have developed a science-informed framework for intervention. However, there is a significant need for further research on the preparation and participation of girls with disabilities in STEM fields. We also need to understand the impact of using labor market data on long-term outcomes of individuals as they enter and continue along their career paths.

\section{References}

Bandara, A. (2015). The economic cost of gender gaps in effective labor: Africa's missing growth reserve. Feminist Economics 21, 162-186. doi:10.1080/13545701. 2014.986153

Bellman, S., Burgstahler, S., \& Chudler, E. H. (2018). Broadening participation by including more individuals with disabilities in STEM: Promising practices from an engineering research center. American Behavioral Scientist, 62, 645-656. doi:10.1177/0002764218768864

Black, S. E., Whitmore Schanzenback, D., \& Breitwieser, A. (2017). The recent declines in women's labor force participation. In D.W. Schanzenbach \& R. Nunn (Eds.), The 51\%: Driving growth through women's economic participation (pp. 5-17). Retrieved from the Brookings Institution website: https://www.brookings. edu/wp-content/uploads/2017/10/es_10192017_ the51 percent_ebook.pdf

Blalock, G., \& Patton, J. R. (1996). Transition and students with learning disabilities: Creating sound futures. Journal of Learning Disabilities, 29(1), 7-16. doi:10.1177/002221949602900104
Bronfenbrenner, U. (1977). Toward an experimental ecology of human development. American Psychologist, 32, 513-531. doi:10.1037/0003-066X.32.7.513.

Bronfenbrenner, U. (1979). The ecology of human development: Experiments by nature and design. Cambridge, England: Harvard University Press.

Burgstahler, S. (2017). Equal access: Universal design of instruction. Retrieved from https://www.washington. edu/doit/sites/default/files/atoms/files/EA_Instruction.pdf

Burning Glass Technologies. (2018). Retrieved from https:// www.burning-glass.com/solutions/education/

Bystydzienski, J. M., Eisenhart, M., \& Bruning, M. (2015). High school is not too late: Developing girls' interest and engagement in engineering careers. Career Development Quarterly, 63, 88-95. doi:10.1002/j.21610045.2015.00097.x

Career One Stop. (2019). Skills assessment. Retrieved from https://www.careeronestop.org/ExploreCareers/Assessments/skills.aspx

Casey Life Skills. (2017). Retrieved from https://caseylifeskills.secure.force.com

Center for Applied Special Technology (CAST). (2011a). UDL: The UDL guidelines. Retrieved from http://udlguidelines.cast.org/

Center for Applied Special Technology (CAST). (2011b). About universal design for learning. Retrieved from http:// www.cast.org/our-work/about-udl.html

Emsi. (2018). Our Data. Retrieved from https://www.economicmodeling.com/

Feldhaus, C., \& Bentrem, K. (2015). STEM mentoring and the use of the principles of adult mentoring inventory. International Journal of Mentoring and Coaching in Education, 4, 213-235. doi:10.1108/IJMCE-11-2014-0039

Fichten, C. S., Asuncion, J. V., Barile, M., Robillard, C., Fossey, M. E., \& Lamb, D. (2003). Canadian postsecondary students with disabilities: Where are they? The $\mathrm{Ca}$ nadian Journal of Higher Education, 33, 71-114. Retrieved from http://journals.sfu.ca/cjhe/index.php/ cjhe/article/view/183441

Fifolt, M., \& Searby, L. (2010). Mentoring in Cooperative Education and Internships: Preparing Protégés for STEM Professions. Journal of STEM Education: Innovations \& Research, 11(1), 17-26. Retrieved from https://www. jstem.org/

Gregory, S. (2016). Stereotypes can be threatening. Retrieved from the American Association of University Women website: https://www.aauw.org/article/stereotypes-can-be-threatening/

Griffiths, A. J., Alsip, J., Hart, S., Round, R. L., \& Brady, J. (in press). Together we can do so much: A systematic review and conceptual framework of collaboration in schools. Canadian Journal of School Psychology.

Griffiths, A. J., Cosier, M., \& Morgan, S. (2019). Research-to-practice brief: Using labor market projections for successful transition planning. Thompson Policy Institute Disability Summit Fourth Annual Report. Orange, CA: Chapman University, Attallah College of Educational Studies. 
Griffiths, A. J., Giannantonio, C. M., Hurley-Hanson, A. E., \& Cardinal, D. (2016). Autism in the workplace: Assessing the transition needs of young adults with autism spectrum disorder. Journal of Business and Management, 22(1) 5-22. Retrieved from https://digitalcommons.chapman.edu/education_articles/231/

Griffiths, A. J., \& Miles Nash, A. (2019). Making STEM education inclusive: Opening doors to engage girls and women with disabilities. Thompson Policy Institute Disability Summit Fourth Annual Report. Orange, CA: Chapman University, Attallah College of Educational Studies.

Hanna, W. J., \& Rogovsky, B. (1991). Women with disabilities: Two handicaps plus. Disability, Handicap \& Society, 6 , 49-63. doi:10.1080/02674649166780041

Harley, E. K. (2011). The impact of interpersonal relationships on postschool employment outcomes and community satisfaction for young women with learning disabilities: An ecological perspective (Doctoral dissertation). Retrieved from ProQuest Dissertation and Theses database. (UMI No. 3485949)

Individuals With Disabilities Education Act, 20 U.S.C. § 14001414 § (2004).

Institute for the Future \& Dell Technologies. (2017). The next era of human machine partnerships report. Retrieved from https://www.delltechnologies.com/content/ dam/ delltechnologies/assets/perspectives/2030/ pdf/SR1940_IFTFforDellTechnologies_Human-Machine_070517_readerhigh-res.pdf

Izzo, M. V., \& Bauer, W. M. (2015). Universal design for learning: enhancing achievement and employment of STEM students with disabilities. Universal Access in the Information Society, 14(1), 17-27. doi:10.1007/s10209-0130332-1

Jones, L. K. (2014). Career key. Retrieved from http://www.careerkey.org/

Joseph, N. M., Hailu, M., \& Boston, D. (2017). Black women's and girls' persistence in the P-20 mathematics pipeline: Two decade of children, youth, and adult education research. Review of Research in Education, 41, 203227. doi:10.3102/0091732X16689045

Justice, H., \& Norwood, C. (2016). Purposeful planning: Using data to drive programs of study. Techniques, 91(6), 41-44. Retrieved from https://www.acteonline.org/ publications/techniques/

Kendricks, K. D., Nedunuri, K. V., \& Arment, A. R. (2013). Minority student perceptions of the impact of mentoring to enhance academic performance in STEM disciplines. Journal of STEM Education: Innovations \& Research, 14(2), 38-46. Retrieved from https://www.jstem.org/

Landuvar, L. C. (2013). Disparities in STEM employment by sex, race, and Hispanic origin (Report No. ACS-24). Washington, DC: U.S. Census Bureau.

Lee, A. (2011). A comparison of postsecondary science, technology, engineering, and mathematics (STEM) enrollment for students with and without disabilities. $\mathrm{Ca}$ reer Development for Exceptional Individuals, 34, 72-82. doi:10.1177/0885728810386591
Marino, M. T. (2010). Defining a technology research agenda for elementary and secondary students with learning and other high-incidence disabilities in inclusive science classrooms. Journal of Special Education Technology, 25(1), 1-27. doi:10.1177/016264341002500101

Mind Tools. (2019). SMART goals: How to make your goals achievable. Retrieved from https://www.mindtools.com/pages/article/get-started.htm

Modi, K., Schoenberg, J., \& Salmond, K. (2012). Generation STEM: What girls say about science, technology, engineering, and math (A Report from the Girl Scout Research Institute). New York, NY: Girl Scouts of the USA.

Muthumbi, J. W. (2008). Enhancing transition outcome for youth with disabilities: The partnerships for youth initiative. Journal of Vocational Rehabilitation, 29, 93-103. Retrieved from https://content.iospress.com/articles/ journal-of-vocational-rehabilitation/jvr00436

Myers and Briggs Foundation. (2019). Take the MBTI Instrument. Retrieved from https://www.myersbriggs.org/ my-mbti-personality-type/take-the-mbti-instrument/ home.htm

National Science Foundation. (2017). Employed women scientists and engineers, as a percentage of selected occupations: 2015. Retrieved from https://www.nsf.gov/statistics/2017/ nsf17310/digest/occupation/women.cfm

Neal, J. W., \& Neal, Z. P. (2013). Nested or networked? Future directions for ecological systems theory. Social Development, 22, 722-737. doi:10.1111/sode.12018

Noonan, R. (2017). Women in STEM: 2017 Update (ESA Issue Brief No. 06-17). Retrieved from the U.S. Department of Commerce website: https://www.commerce.gov/ sites/default/files/migrated/reports/women-in-stem2017-update.pdf

O'Day, B., \& Foley, S. (2008). What do we know, and not know, about women with disabilities in the workforce? Impact: Feature Issue on Employment and Women With Disabilities, 21(1), 4-5. Retrieved from https://ici.umn.edu/ products/impact/211/211.pdf

O*Net Resource Center. (2019). Tools. Retrieved from https:// www.onetcenter.org/tools.html

PAIRIN. (2017). Soft skills assessment. Retrieved from https:// pairin.com/soft-skills-assessment/

Rashid, B. (2016). Rise of the freelance economy. Forbes. Retrieved from https://www.forbes.com/sites/brianrashid/2016/01/26/the-rise-of-the-freelancer-economy/

Rowe, D. A., Mazzotti, V. L., Hirano, K., \& Alverson, C. Y. (2015). Assessing transition skills in the 21st century. TEACHING Exceptional Children, 47, 301-309. doi:10.1177/0040059915587670

Schreffler, J., Vasquez, E., III, Chini, J., \& James, W. (2019). Universal design for learning in postsecondary STEM education for students with disabilities: A systematic literature review. International Journal of STEM Education, 6(8), 1-10. doi:10.1186/s40594-019-0161-8 
Simplican, S. C., Leader, G., Kosciulek, J., \& Leahy, M. (2015). Defining social inclusion of people with intellectual and developmental disabilities: An ecological model of social networks and community participation. Research in Developmental Disabilities, 38, 18-29. doi:10.1016/j.ridd.2014.10.008

Society of Women Engineers. (2018). Fast facts. Retrieved from https://research.swe.org/wp-content/uploads/2018/10/18-SWE-Research-Flyer_FINAL.pdf

Spencer, S. J., Steele, C. M., \& Quinn, D. M. (1999). Stereotype threat and women's math performance. Journal of Experimental Social Psychology, 35(1), 4-28. doi:10.1006/jesp.1988.1373

Stamp, L., Banerjee, M., \& Brown, F. C. (2014). Self-advocacy and perceptions of college readiness among students with ADHD. Journal of Postsecondary Education and Disability, 27(2), 139-160.

Steele, C. M., \& Aronson, J. (1995). Stereotype threat and the intellectual test performance of African Americans. Journal of Personality and Social Psychology, 69, 797811. doi:10.1037/0022-3514.69.5.797

Sumi, V. S. (2012). Education and gender discrimination. Paper presented at the National Seminar on Women's Human Rights - A Feminist Discourse, Maulana Azad National Urdu University, Hyderabad, India. Retrieved https://files.eric.ed.gov/fulltext/ED543630. pdf

Tabak, L. A., \& Collins, F. S. (2011). Weaving a richer tapestry in biomedical science. Science, 333(6045), 940-941. doi:10.1126/science.1211704

Turnbull, A. (2010). Transitioning to enviable lives for adults with autism and beyond evidence-based practice: Wisdom-based action as a process of facilitating IDEA outcomes (Mollie Villeret Davis Lecture). Retrieved from https://repositories.lib.utexas.edu/handle/2152/74308

Turnbull, H. R., Turnbull, A. P., \& Cooper, D. (2018). The supreme court, Endrew, and the appropriate education of students with disabilities. Exceptional Children, 84, 124-140. doi:10.1177/0014402917734150

U.S. Department of Education, Office of Special Education and Rehabilitative Services. (2017). A transition guide to postsecondary education and employment for students and youth with disabilities. Washington, DC: Author.

U.S. Department of Labor, Bureau of Labor Statistics. (2017a). Employment projections. Retrieved from https://www.bls.gov/news.release/ecopro.nro.htm

U.S. Department of Labor, Bureau of Labor Statistics. (2017b). May 2017 National occupational employment and wage estimates United States. Retrieved from https://www.bls.gov/oes/ current/oes_nat.htm

U.S. Department of Labor, Bureau of Labor Statistics. (2018a). Fastest growing occupations, 2016 and projected 2026. Retrieved from https://www.bls.gov/ emp/tables/fastest-growing-occupations.htm

U.S. Department of Labor, Bureau of Labor Statistics. (2018b, June 21). Persons with a disability: Labor force characteristics news release [Press release]. Retrieved from https://www.bls.gov/news.release/disabl.htm
Walrod, W., \& Walrod, P. (2018). Labor market analytics report [Internal unpublished report]. Retrieved from https://www.qidianusa.com/

World Economic Forum. (2018). Future jobs report. Retrieved from http://www3.weforum.org/docs/WEF_Future of_Jobs_2018.pdf 